\title{
Blavatsky the Satanist: Luciferianism in Theosophy, and its Feminist Implications
}

\author{
PER FAXNELD \\ Stockholm University
}

\begin{abstract}
H. P. Blavatsky's influential The Secret Doctrine (1888), one of the foundation texts of Theosophy, contains chapters propagating an unembarrassed Satanism. Theosophical sympathy for the Devil also extended to the name of their journal Lucifer, and discussions conducted in it. To Blavatsky, Satan is a cultural hero akin to Prometheus. According to her reinterpretation of the Christian myth of the Fall in Genesis 3, Satan in the shape of the serpent brings gnosis and liberates mankind. The present article situates these ideas in a wider nineteenth-century context, where some poets and socialist thinkers held similar ideas and a counter-hegemonic reading of the Fall had far-reaching feminist implications. Additionally, influences on Blavatsky from French occultism and research on Gnosticism are discussed, and the instrumental value of Satanist shock tactics is considered. The article concludes that esoteric ideas cannot be viewed in isolation from politics and the world at large. Rather, they should be analyzed both as part of a religious cosmology and as having strategic polemical and didactic functions related to political debates, or, at the very least, carrying potential entailments for the latter.
\end{abstract}

Keywords: Theosophy, Blavatsky, Satanism, Feminism, Socialism, Romanticism.

In September 1875, Helena Petrovna Blavatsky (1831-1891) co-founded the Theosophical society in New York City. Colonel Henry Steel Olcott (1832-1907), lawyer and journalist, was elected its first president. Blavatsky, however, became the chief ideologist, drawing authority from the communications concerning esoteric matters she claimed to receive from the mysterious 'Mahatmas' (or 'Masters'). Allegedly with their help, she composed the foundation texts of Theosophy, Isis Unveiled (1877) and The Secret Doctrine (1888). Both became worldwide best-sellers, and, as is well known, the Society came to occupy a position as the most important international movement of its time in the realm of alternative spirituality.

A fact little discussed by scholars concerning Blavatsky's voluminous (close to 1,500 pages) and vastly influential The Secret Doctrine is that it 
contains passages of unembarrassed and explicit Satanism. ${ }^{1}$ The almost total neglect of these ideas is probably often due to a feeling that they are unimportant to Theosophy at large. It may also partly have something to do with scholars simply not knowing what to make of the matter. The following should be perceived as a preliminary attempt to achieve a contextual understanding. My argument is that Blavatsky's sympathy for the Devil (which is not quite as peripheral as has been supposed) needs to be understood not only as part of an esoteric worldview, but that we must also consider the political - primarily feminist - implications of such ideas. Further, taking into account for instance contemporary scholarly theories, art and literature we will reach a better comprehension of the cultural logic underpinning Blavatsky's use of Satanist discourse. A final dimension which I argue is of importance, and which Blavatsky herself stresses, is the use of Satanism as a pedagogical tool.

First I will provide some background information on Blavatsky as a person, Theosophy as protest movement and counter culture, and its links with socialism and feminism. ${ }^{2}$ I will then proceed to scrutinize Blavatsky's celebrations of Satan, and try to make sense of them in relation both to the aforementioned connections and to Romantic literature and art, evolutionism, contemporary research on Gnosticism and strategic polemical motives.

\section{The Enigmatic Madame Blavatsky}

Almost 600 (!) biographies have been written of Blavatsky, but the details of her life, especially the years 1848-1873, remain sketchy all the same. Most of the authors have been either devoted disciples or sharply critical adversaries. Some interesting and well-documented facts, however, can be determined. She was born to a noble Russian family in present-day Ukraine, married at 17, ran away only months later, traveled widely and spent time in Cairo, among many other places, where she supported herself as a medium. In the category of details considered doubtful by her detractors, we find Blavatsky's claims to having studied voodoo in New Orleans, crossing the prairie in the

\footnotetext{
1 Both 'Satanism' and 'Luciferianism', as used in the present article, should (in contrast to the more strict use I have advocated elsewhere, e.g. Faxneld 2006, xiii-xvi) be understood simply as a label for the use of Satan as a positive symbol, even in a limited context, not as necessarily referring to a well-developed system centered around a favorable understanding of this figure. As will be seen, the esoteric system constructed by Blavatsky could certainly not as a whole be designated 'Satanism', though such elements are clearly present.

2 The word feminism is, of course, anachronistic in the time context of the present article, and is utilized simply as a broad term for various forms of struggles for women's rights.
} 
company of native Americans, and spending seven years with the 'Masters' in Tibet. Her adversaries' claims about bigamy, an abandoned infant, and charlatanry are equally contested by pro-Blavatsky writers. In 1873 she moved to New York City, where the Theosophical Society was founded two years later. Together with Olcott, she relocated to India in 1879, returning to Europe in 1886. She died in London in 1891, famous all over the world as one of the most unconventional and extravagant women of her age. While she was the only one to reach international fame, independent women were common in the family: her mother came to prominence in Russia as a feminist author in the 1840's and her grandmother was a self-taught botanist, both leading lives defying contemporary ideas about appropriate behavior for women (Kraft 2003, 127-8).

Blavatsky was very hostile towards Christianity as an organized religion, though not towards the true esoteric core she claimed it (like all other major religions) possessed. In effect, however, this meant she was harshly critical of the effects of Christianity as a historical phenomenon, in terms both of the existing churches and of established Christian theology, i.e. of all its noteworthy past and present manifestations. In The Secret Doctrine, she writes: 'The esoteric pearl of Christ's religion degraded into Christian theology, may indeed be said to have chosen a strange and unfitting shell to be born in and evolved from' (Blavatsky 1888a, 442). In Isis Unveiled, there are chapters with names like 'Christian Crimes and Heathen Virtues' and 'Esoteric Doctrines of Buddhism Parodied in Christianity'. Blavatsky despised the Christian idea of a personal God, and underscored that her belief in God should be understood as pantheistic in a Buddhist sense rather than theistic in a Christian sense. Indeed, Blavatsky and Olcott took pansil (Pali: pancha sila) when they visited Ceylon in May 1880, and she had considered herself a Buddhist already back in New York. In an 1877 letter, for example, she frankly declared: 'I am a Svabhavika, a Buddhist pantheist, if anything at all. I do not believe in a personal God, in a direct Creator, or a "Supreme"; neither do I confess to a First cause, which implies the possibility of a Last one' (Godwin 1994, 322). As we shall see, nor did she, accordingly, acknowledge the existence of a personal Satan.

Blavatsky was often perceived as a quite vulgar and coarse person. She swore profusely, dressed garishly, and had a strong sense of irreverent humor. Her New York study was decorated with a stuffed baboon wearing white collars, cravats and spectacles, carrying a manuscript bundle under his arm labeled 'The Descent of the Species' (Blavatsky rejected Darwin's ideas about man being descended from apes) (Campbell 1980, 76). It is not 
hard to imagine that such a lady would derive considerable pleasure from upsetting Christians with a pinch of esoteric Satanism. What I shall focus on here, however, is not her personality, though that aspect will not be entirely ignored, but rather the ideas concerning Satan as a liberator figure that were current in contemporary culture, as well as the ties between Theosophy and radical movements like socialism and feminism, all of which might serve to further understanding of the cultural logic behind Theosophical Luciferianism.

\section{Theosophy as Protest Movement and Counter Culture}

Unlike the occultism presented earlier by Éliphas Lévi and similar authors, which mostly caught the interest only of a small circle of freethinkers, Theosophy fast became a successful semi-mass movement. By 1889 the Theosophical Society had 227 sections all over the world, and many of the era's most important intellectuals and artists were strongly influenced by it. Avant-garde painters, especially, took this new teaching to heart, and it marked the work of great artists such as Mondrian, Kandinsky and Klee. In literature, authors like Nobel Prize laureate William Butler Yeats became members and incorporated Theosophical motifs in their writings (Lejon 1997, 43; Szalczer 1997, 48-56; Sellon \& Weber 1992, 326-7).

Often, the markedly anti-clerical Theosophy movement also allied itself with other forces working for social and religious liberation, including suffragettes, socialists and the aforementioned modernist avant-garde in literature and art. Yet, the relationship to such forces of upheaval and reform seems to have been a troubled one at times, and there were also elements present within Theosophy that were conservative in most questions other than the religious ones. Joy Dixon argues, all the same, that the Theosophical Society under Annie Besant's leadership (1907-1933) was, at least in England, 'an important part of a loosely socialist and feminist political culture' (Dixon 2001, 150).

As Stephen Prothero (among others) has shown, Theosophy originated in Spiritualism. This fact is important for an understanding of its relation to various forms of radicalism and the internal struggles between elitism and democratic impulses. In Prothero's view, Theosophy began as an attempt by members of an elite to reform 'vulgar' Spiritualism, considered by many scholars a populist movement, by uplifting its adherents from their ghost seeking into the lofty realms of 'ethically exemplary theorists of the astral planes', as he describes it (Prothero 1993, 198). It is worth noting that 
in his critique of Spiritualism (written shortly before the founding of the Theosophical Society), Olcott reproached it for the presence of 'free-lovers, pantarchists, socialists, and other theorists who have fastened upon a sublime and pure faith as barnacles upon a ship's bottom' (quoted in Prothero 1993, 203). In his first presidential address as the head of the Theosophical Society, in November 1875, Olcott railed against 'tricky mediums, lying spirits, and revolting social theories' in Spiritualism (quoted in Prothero 1993, 206, my italics). This is not to deny Olcott was concerned to achieve utopian social transformations, and his rhetoric proclaimed that the cultivation of noble traits in Theosophists would lead to such general change.

Blavatsky, on the other hand, focused exclusively on the uplifting of oneself rather than others. To Prothero, this is simply 'the difference between Russian aristocracy and metropolitan gentility' (Prothero 1993, 208). It is worth keeping in mind, however, that for example Kropotkin and Bakunin both came from noble Russian families, so her attitudes are perhaps not best explained by her family background. ${ }^{3}$ Of greater significance, in my opinion, are Blavatsky's strong ties to more traditional and formalized Western esotericism, such as fringe masonry and hermetic orders. Members of these groups were to a higher degree than Spiritualists non-egalitarian and conservative in orientation (for examples of such right-wing tendencies, see Hutton 1999, 360-1; on Blavatsky's connections of this type, see Godwin 1994), but could simultaneously embrace at least some elements of radicalism and anti-establishment sentiments, which helps explain Blavatsky's at times ambivalent attitude in these matters.

\section{Theosophy and Socialism}

It is amusing in this context to note that Richard Hodgson's 1885 report on Blavatsky, written for the Society for Psychical Research and denouncing her as a fraud, concludes that the true objects of the Theosophical Society were political, and that Blavatsky was in fact a Russian spy (Santucci 2006, 182).

However, Blavatsky was hardly a spy for the Tsar; nor was she a socialist, but Theosophy was, to some extent at least, part of a wider radical community, and she had close associates, like Charles Sotheran (1847-1902), who were dedicated socialists (Godwin 1994, 283-5; Johnson 1994, 80-9). Sotheran was one of the original founders of the Theosophical Society and its first

3 On the other hand, the fact that Kropotkin and Bakunin, when they turned to socialism, became anarchists rather than communists may indeed have had something to do with their aristocratic background. 
librarian. This is not to say she sympathized with socialism per se at all, and in her scrapbook she even wrote about Sotheran: 'a friend of Communists is not a fit member of our Society' (Johnson 1994, 81). In spite of Blavatsky's disdain for contemporary socialist activism, she occasionally had kind words in store for more mythical historical examples of it: she approvingly called Jesus 'the great Socialist and Adept' (quoted in Godwin 1994, 292).

Further, Blavatsky's personal views did not, of course, determine the full extent of socialist-Theosophist interaction. Her cosmic concepts could potentially be useful for socialists regardless of how she felt about them. For example, the immanentist doctrine formulated by Blavatsky lent itself very well to legitimizing socialist ideas, since her organic vision of a world where all is one clearly challenged atomizing liberal ideas about the state as an association of completely autonomous individuals. The dissolving of boundaries between human beings in esoteric discourse could, as Dixon suggests, be seen as implicitly linked to a political socialist ideal of universal brotherhood and equality (Dixon 2001, 123). ${ }^{4}$ However, it could also be argued that Dixon overlooks the fact that a vision of society as an organic unity, though one with hierarchic divisions where some people are the head and others the feet et cetera, is also a classic view among conservatives.

Lastly, one can ask, as Siv Ellen Kraft does, why Blavatsky, if she was so critical of social reform, and socialism in particular, chose Annie Besant to be her successor, given that the latter's fame rested on her endeavors as a socialist agitator (Kraft 1999, 64). To summarize, Theosophical interaction with socialism was complex. There were definitely red sympathizers present within the organization, even if Blavatsky and Olcott both rejected socialism fairly outright. As we shall see, there is still a chance Blavatsky might have been introduced to some of the contemporary mytho-rhetorical tropes of socialism through her associates, which may have influenced her conception of Satan.

\section{Theosophy and Feminism}

The Theosophical Society in its entirety was never officially committed to a political or even philanthropic program. The central tenet of universal brotherhood did still tend to be used as a justification for local lodges to work towards improving conditions for the needy, for example by establishing

4 Dixon notes that there was nothing inevitable about immanentist theology leading to socialist inferences; rather, active work with the material was needed to turn it to such ends (Dixon 2001, 124). 
orphanages and crèches. It is important to keep in mind this was hardly unique, however, and mainstream religious organizations also engaged in similar activities. More irregular was their positive attitude towards female leadership. The prominent position of Blavatsky - and later, to an even greater extent, Besant - probably furthered the influx of female members who viewed Theosophy as sympathetic towards feminism. The ties to socialist and feminist currents were strengthened under Besant's leadership, and in this period the immanentist theology developed by Blavatsky came to be used as a justification for social reform (Dixon 2001, 133-7, 154). ${ }^{5}$

According to Siv Ellen Kraft, throughout the period from 1880 to 1930 there existed a considerable overlap between Theosophy and the women's movement, in particular in England, Australia, the United States and India (Kraft 2003, 125-6). Mary Farell Bednarowski, on the other hand, probably exaggerates slightly when she states that there was an explicit concern for equality between the sexes from the very beginning of the Theosophical Society. She makes this claim based on the first objective of the Society 'to form the nucleus of a Universal Brotherhood of Humanity, without distinction of race, sex, caste, or color' (Bednarowski 1980, 221). In fact, the objectives were not formulated until 1878-79, several years after the founding of the organization, and sex is not even mentioned in several versions of the objectives, which went through many revisions (Prothero 1993, 197-8). Even more importantly, far from all members seem to have felt the first objective by necessity implied that equality between the sexes, in an absolute sense, was desirable.

The role of feminism in the Theosophical Society was a complicated affair, which involved ongoing negotiations and battles, making it at times quite prominent and suppressing it at others. For example, arguments were put forward that proper Theosophy was a masculine teaching, unlike the detested Christianity which was sentimental and feminine. On the other hand, we can for instance think of the feminist Henrietta Müller (1845-1906), who, before joining the Theosophical Society in 1891, wrote to Blavatsky and asked her if women in the organization enjoyed equal rights, and received the answer that they indeed did. Further, Blavatsky insured her they could, just like men, aspire to the position of Adepts or Mahatmas (Dixon 2001, 64, 68, 174). In August 1890, Blavatsky wrote in the Theosophical journal Lucifer about an 'admirable address' by a leading feminist, F. Fenwick Miller, men-

5 Concerning Besant and feminism it should be noted that many (e.g. Johnson 1995, 196-7) have commented on Besant's tendency to hero-worship various male figures as well as her sustained focus on male external authority. 
tioning that many Theosophists were members of her Women's Franchise League and critiquing the fact that in England a woman 'was and still is' a 'thing and her husband's chattel' rather than 'an independent individual and a citizen' (Blavatsky 1890, 472). Later, in 1918, the Theosophist Margaret Cousins could write glowingly of Blavatsky: 'Our greatest magician of later times saw no reason for excluding women from priestly office' (quoted in Kraft 1999, 104).

Ultimately, teaching by example was perhaps more important than words in this matter. Blavatsky's solitary journeys before arriving in New York, which may not have been quite as wide-ranging as she herself made them out to be, were acts of transgression, since it was considered highly unsuitable for a female to travel on her own. Her stories about dressing up in men's clothing when needed during these trips, and even taking up arms alongside Garibaldi at the battle of Mentana, further underscore her rejection of traditional womanhood. (Sellon \& Weber 1992, 312; Kraft 2003, 132.) She herself went so far as to claim: 'there is nothing of the woman in me' (quoted in Kraft 2003, 134). A pronounced skepticism towards the institution of marriage - speaking for instance of 'the risks of that lottery where there are so many more blanks than prizes' (quoted in Bednarowski 1980, 223) also made her very much out of tune with Victorian ideals of womanhood. Even if the Masters, by selecting Blavatsky as their mouthpiece, seemingly give spiritual authority to women, the actual views on women expressed in the letters they supposedly wrote mostly consist of flippant remarks (that appear to be half-joking). Yet, since the Masters apparently choose female pupils from the ranks of the 'New Women' (independent, but not always explicitly feminist), they thus appear to encourage women to break free from social constrictions in order to realize their full spiritual potential (Kraft 1999, 32, 147). Blavatsky would not have considered herself a feminist, and seems to have been skeptical of political reform movements in general. But, as Kraft observes, she still made a feminist contribution, by destabilizing gender categories in words and deeds (Kraft 1999, 145; 2003, 126).

Having established some important background facts, it is now time to examine the Satanist content in Blavatsky's writings, its potential links with socialism, and its feminist implications.

\section{Satan in Blavatsky's Two Major Works}

The two most widely spread books by Blavatsky (though perhaps not the most widely read, at least not in their entirety, given how voluminous they 
are: over 1,200 and almost 1,500 pages respectively) were Isis Unveiled (1877) and The Secret Doctrine (1888). They were hugely commercially successful, with the first book selling roughly half a million copies up until 1980. Both were written with much help from several collaborators. For Isis Unveiled Blavatsky was assisted by Olcott, who edited her text heavily and wrote some sections himself. The work on the second book was somewhat similar. The chaotic and utterly disorganized manuscript of several thousand pages, making a pile over three feet high, that Blavatsky brought with her to London in 1887 was edited into something manageable by Archibald and Bertram Keightley in cooperation with a number of other young Theosophists. The junior scientist Ed Fawcett helped with quotations and wrote many pages for the sections on science (Campbell 1980, 32-5, 40-1). Both these works are thus collaborative efforts. However, I have found no mention of anyone else having been specifically involved with the passages where Blavatsky reinvents various Biblical narratives and praises Satan, and shall hence here assume they were written more or less by her alone.

Academic commentators have frequently remarked on the incoherence and abstruseness of Blavatsky's books, while Theosophists tend to claim there is actually an underlying red thread to be found - at least for the initiated. Even in a scholarly context, some have taken an extremely sympathetic stance concerning the coherence of Blavatsky's texts. Emily B. Sellon and Renée Weber write:

Works like The Secret Doctrine are so full of ambiguities, digressions, and overlapping symbologies that they bewilder and frustrate the casual reader. The use of paradox and symbolic language as a valid method for conveying truth is, however, central to the theosophical epistemology, which regards the awakening of intuition (buddhi) as essential to spiritual growth. (Sellon \& Weber 1992, 320.)

While the texts will admittedly begin to make more sense the deeper one penetrates into Blavatsky's symbolic world, they are still characterized by a great deal of confusion that surely does not lie solely with the uninitiated reader. Therefore, the following discussion does not attempt to extract a totally consistent doctrine from the texts, but rather, to bring out from the contradictions and uncertainties the instances of identifiable underlying structures of thought while simultaneously highlighting the inconsistencies.

Already in Isis Unveiled, Blavatsky discussed the Devil in some detail. Her chapter about the figure here is, however, mostly a sarcastic exposé of the 
beliefs held by Christians concerning the Devil, which she found singularly ridiculous. No celebration of the figure worth mentioning is to be found (Blavatsky [1877]/1988, Vol. II, 473-528). The only tendency in that direction is a short encapsulation - half a page in a 56 page chapter - of a Kabalistic view of Satan as a blind antagonistic force that is necessary for the vitality, development and vigor of the principle of good (Blavatsky [1877]/1988, Vol. II, 480, 500). Satan is also mentioned in a handful of other places in this book, outside of the chapter dedicated to him, but in most instances what we find are variations of phrasings like 'the existence of the Devil is a fiction, which no theology is able to demonstrate' (Blavatsky [1877]/1988, Vol. I, 472). In the eleven years between this work and her celebrated The Secret Doctrine, Blavatsky changed her views on several topics. Earlier, she dismisses the concept of reincarnation, but now she comes to staunchly advocate it (Hammer 1999, 226-7). Satan, too, is seen in an entirely different way. She now affords him two chapters instead of one, and he becomes an explicitly positive symbol.

Blavatsky argues that Satan - or Lucifer, or the Devil, as she often uses the names interchangeably (e.g. Blavatsky 1888a, Vol. II, 510-3) - brought mankind spiritual wisdom, and is 'the spirit of Intellectual Enlightenment and Freedom of Thought' (Blavatsky 1888a, Vol. II, 162). ${ }^{6}$ Like the Romantics, she draws a parallel between Satan and Prometheus (Blavatsky 1888a, Vol. II, 244). Satan's function as a cultural hero in the same spirit as the Greek Titan is evident in the Bible, she claims, provided it is read correctly:

[...] it is but natural - even from the dead letter standpoint - to view Satan, the Serpent of Genesis, as the real creator and benefactor, the Father of Spiritual mankind. For it is he who was the 'Harbinger of Light', bright radiant Lucifer, who opened the eyes of the automaton created by Jehovah, as alleged; and he who was the first to whisper: 'in the day ye eat thereof ye shall be as Elohim, knowing good and evil' - can only be regarded in the light of a Saviour. An 'adversary' to Jehovah the 'personating spirit', he still remains in esoteric truth the ever-loving 'Messenger' (the angel), the Seraphim and Cherubim who both knew well, and loved still more, and who conferred on us spiritual, instead of physical immortality - the latter a kind of static immortality that would have transformed man into an undying 'Wandering Jew'. (Blavatsky 1888a, Vol. II, 243.)

6 In accordance with Blavatsky's usage, and out of a stylistic concern for variety, I also use these different names interchangeably. 
This is a Gnostic-Satanic counter-reading of Genesis 3 that is strangely at odds with Blavatsky's overall cosmology. Elsewhere, she clearly states there is no creator God, and no opposition between God and Satan, both of which are but powers within man himself, each useful in its own right (e.g. Blavatsky 1888a, Vol. II, 389, 478, 513). All this is contradicted in the passage quoted above, where God created man, Satan freed him from the shackles of this demiurge and both are, oddly, much like sentient personages with an independent existence.

The description of events in Genesis, Blavatsky says, needs to be interpreted allegorically in order for the core of true events to be discerned behind the veils of mythical ornamentation. There can be no doubt that Blavatsky views the figure of Satan in this narrative as an unequivocally good force, a helper and friend of mankind:

'Satan', once he ceases to be viewed in the superstitious, dogmatic, unphilosophical spirit of the Churches, grows into the grandiose image of one who made of terrestrial a divine man; who gave him, throughout the long cycle of Maha-kalpa the law of the Spirit of Life, and made him free from the Sin of Ignorance, hence of death (Blavatsky 1888a, Vol. I, 198).

\section{The Prince of Anarchy and the Astral Light}

When quoting the French occultist Éliphas Lévi's linking of Satan and anarchism in a passage from his Histoire de la Magie (1860), Blavatsky touches briefly upon the political dimension of celebrating Lucifer. In the quotation as she gives it, Lévi seems to praise the fallen angel, and proclaims that Satan was 'brave enough to buy his independence at the price of eternal suffering and torture; beautiful enough to have adored himself in full divine light; strong enough to reign in darkness amidst agony, and to have built himself a throne on his inextinguishable pyre.' This figure, 'the Satan of the Republican and heretical Milton', Lévi designates 'the prince of anarchy, served by a hierarchy of pure Spirits'. Blavatsky adds '(! !)' to the mention of pure spirits serving the Devil (Blavatsky 1888a, Vol. II, 506-7). She then comments:

This description - one which reconciles so cunningly theological dogma and the Kabalistic allegory, and even contrives to include a political compliment in its phraseology - is, when read in the right spirit, quite correct. Yes, indeed; it is this grandest of ideals, this ever-living symbol - nay apotheosis - of 
self-sacrifice for the intellectual independence of humanity; this ever active Energy protesting against Static Inertia - the principle to which Self-assertion is a crime, and Thought and the Light of Knowledge odious. [...] But Eliphas Levi was yet too subservient to his Roman Catholic authorities; one may add, too jesuitical, to confess that this devil was mankind, and never had any existence on earth outside of that mankind. (Blavatsky 1888a, Vol. II, 507.)

Blavatsky here misrepresents or possibly misreads Lévi, even though she does describe him as being ironic (Blavatsky 1888a, Vol. II, 507). In fact, what Lévi does is simply to relate a conception of Satan held by Milton, which he deems completely erroneous, himself describing the figure as 'le faux Lucifer de la légende hétérodoxe' (Lévi 1860, 16). Lévi calling Milton a republican and a heretic is not intended as a compliment, and the same goes for the labeling of Satan as 'the prince of anarchy' - Lévi himself, having long-since abandoned the socialist ideas he held in his youth, was firmly conservative by the time he wrote this book. It is interesting that Blavatsky, usually no friend of socialism, here for some reason evidently thinks it 'a political compliment' to be the lord of the anarchists.

Lévi certainly did not advocate an esoteric Satanism, but in some of his works Satan is interpreted as synonymous with what he called the astral light - a force pervading the entire universe, that can be used for both good and evil purposes (e.g. Lévi 1860, 195-7; Faxneld 2006, 101-7). ${ }^{7}$ He hereby somewhat relativized the understanding of the figure among occultists, and prepared the way for Blavatsky's more straightforward pro-Satanic speculations. Lévi was one of her most important sources of inspiration, and in Isis Unveiled he is the most prominent reference (being quoted on no less than 33 separate occasions), as has been pointed out by several scholars (e.g. Eliade 1976, 49; Campbell 1980, 25). In The Secret Doctrine, Lévi remains important at least for the conception of Satan, even if Blavatsky criticizes Lévi for trying to reconcile his ideas with the dogma of the Catholic Church. Blavatsky placed no such constraints upon herself. Her celebration of Satan goes much farther than the ambiguous ideas of Lévi concerning Satan as the astral light. Yet this basic concept still largely underlies her understanding of the Devil as an impersonal force permeating man and cosmos, making both dynamic.

7 It should be noted that he also identified the astral light with, among other things, the Holy Spirit. 


\section{Gnosticism and the Devil within Us}

Aside from Lévi, another important building block of the Blavatskian Weltanschauung came from contemporary (semi-)scholarly understandings of ancient Gnosticism. Among the books Blavatsky drew most heavily upon (and at times even quoted verbatim, without mentioning that the words were not her own) when she wrote Isis Unveiled was C. W. King's The Gnostics and Their Remains (1864, revised ed. 1887). As Campbell has pointed out, the term gnosis is consistently prominent in her technical vocabulary (Campbell 1980, 33-4, 37). Gnosticism plays an important part in The Secret Doctrine as well, and King is referenced in the discussion concerning Satan (Blavatsky 1888a, Vol. II, 243). ${ }^{8}$ In King's account of Gnostic ideas, there is little support for a positive view of Satan, and maintaining the later Christian identification of the serpent in Eden with the Devil, which the Gnostics did not ascribe to, is Blavatsky's own initiative. In spite of such divergences, she explicitly points to the Gnostics as the best source if one wants to understand the true meaning of the supposedly evil powers symbolized by the dragon, the serpent and the goat (Blavatsky 1888a, Vol. II, 386). The Christian Church, on the other hand, has of course completely misunderstood their significance:

[...] that which the clergy of every dogmatic religion - pre-eminently the Christian - points out as Satan, the enemy of God, is in reality, the highest divine Spirit - (occult Wisdom on Earth) - in its naturally antagonistic character to every worldly, evanescent illusion, dogmatic or ecclesiastical religions included (Blavatsky 1888a, Vol. II, 377).

Satan fulfills a most necessary function not only for mankind, but also for God, Blavatsky claims: 'God is light and Satan is the necessary darkness or shadow to set it off, without which pure light would be invisible and incomprehensible' (Blavatsky 1888a, Vol. II, 510). This is not to say that Satan is God's adversary, she states, since they are in a sense one, identical, or two sides of the same coin (Blavatsky 1888a, Vol. II, 515). Blavatsky also insists on the unity of Jehovah and the serpent that tempted Eve. They are one and the same, and only the ignorance of the Church Fathers has degraded the serpent into a devil (Blavatsky 1888a, Vol. I, 73). These might seem like unnecessary points to make for a monist, to whom of course everything is

8 It must be stressed that the sources traced in this article most likely only represent a fraction of those utilized by Blavatsky, since she is notorious for her innumerable borrowings and plagiarisms from a vast plethora of different types of texts. 
ultimately one. But this monist is a strong believer in evolution. Everything being one does not entail that stasis is desirable, and for evolution to run its course there is a need for (seemingly) antagonistic forces. Satan and evil, she proposes, have an important part to play in evolution: 'Evil is a necessity in, and one of the supporters of the manifested universe. It is a necessity for progress and evolution, as night is necessary for the production of Day, and Death for that of Life - that man may live for ever'. (Blavatsky 1888a, Vol. II, 389.) Given the heavy focus on evolution in Theosophy it is also unsurprising that the development in man set in motion by the Fall should be considered something positive. In the Theosophical cosmology, the nature of the universe is forward motion (Sellon \& Weber 1992, 322). Mankind breaking free from stasis, disrupting equilibrium by eating the forbidden fruit, is therefore logically a fortunate event (in a rather different sense than Aquinas' felix culpa).

The creature causing this event seems to have been man himself, with no help from an external serpent or Satan. Blavatsky explicitly denies the existence of Satan 'in the objective or even subjective world (in the ecclesiastical sense)' (Blavatsky 1888a, Vol. II, 209). That Satan does not exist in the ecclesiastical sense does not mean he lacks existence. Blavatsky simply locates him elsewhere than in a fiery hell: '[...] Satan, or the Red Fiery Dragon, the "Lord of Phosphorus" (brimstone was a theological improvement), and Lucifer, or "Light-Bearer", is in us: it is our Mind - our tempter and Redeemer, our intelligent liberator and Saviour from pure animalism' (Blavatsky 1888a, Vol. II, 513). Blavatsky proclaims that 'esoteric philosophy shows that man is truly the manifested deity in both its aspects - good and evil' (Blavatsky 1888a, Vol. II, 515). God and Satan are thus both aspects contained within man himself. They are still directly connected to the divine, and Blavatsky explains that Satan is 'the emanation of the very essence of the pure divine principle Mahat (Intelligence), which radiates direct from the Divine mind'. Without Satan, 'we would be surely no better than animals'. (Blavatsky 1888a, Vol. II, 513.)

A rather jarring discrepancy is obviously present in Blavatsky's image of Satan. While the figure is on the one hand described in a monist fashion as synonymous with Jehovah (who in turn is an aspect of man himself), elsewhere - as we have seen - he is depicted more as a noble rebel against an unjust God, both of whom are described as conscious separate entities. That symbolic language is being used does not quite account for this inconsistency. 


\section{Lucifer: 'an assertion of free-will and independent thought'}

Blavatsky's sympathy for the Devil was evinced even before the publication of The Secret Doctrine. From September 1887 onwards, Blavatsky published a journal named Lucifer. The initiating of this project can be seen as part of the ongoing power struggle between her and Olcott, and it was to serve as an alternative to the periodical under his control, The Theosophist (Prothero 1993, 210; Campbell 1980, 97-100). She insisted the name of her journal was definitely not an expression of Satanism, though there can be little doubt that the name was chosen partly in order to provoke the Church and other ideological opponents. The strikingly positive view of Satan presented the next year by Blavatsky in The Secret Doctrine also makes it obvious that a double entendre of some kind was intended. In the editorial for the first issue, Blavatsky (judging by the style, almost certainly the author) dismisses the misunderstanding of the name Lucifer as exclusively infernal, and claims that 'the title for our magazine is as much associated with divine and pious ideas as with the supposed rebellion of the hero of Milton's "Paradise Lost"' (Editor 1887, 6). But in the same editorial she also writes about Satan in 'Milton's superb fiction' that if one analyzes his rebellion, 'it will be found of no worse nature than an assertion of free-will and independent thought, as if Lucifer had been born in the XIXth century' (Editor 1887, 2), in other words practically presenting Satan as a freedom fighter. It seems she also figured the shock value of the name could serve a pedagogical purpose: 'to force the weak-hearted to look truth straight in the face, is helped most efficaciously by a title belonging to the category of branded names' (Editor $1887,2) .{ }^{9}$

In a debate initiated by a letter from the Reverend T. G. Headley in the August 1888 issue of Lucifer, some additional light is shed on what ideas concerning Satan were propagated in the Theosophical Society and more specifically in the journal in question. Headley argues that the priests of Jesus' time caused the son of God to be slain as a devil. The priests then went on to appropriate the figure of Christ and establish various false doctrines in his name. The ones most properly labeled devils are therefore these priests. But we must be careful, Headley warns, not to dethrone Christ in our struggle against the devilish priests. The editors simply respond that

9 The somewhat drastic and provocative title of the present article was conceived with Blavatsky's attention-grabbing tactic in mind (since you are reading this, it apparently worked as planned), reflecting and demonstrating her approach. As will be seen in the conclusion, I do not believe the label 'Satanist', in a strict sense, is appropriate to apply to Blavatsky, even though she did employ a 'Satanist' discourse in limited contexts. 
they agree Christ should indeed be honored, as an initiate, while Catholicism and Protestantism should be rejected. (Headley 1888a; Editor 1888a.) One Thomas May felt moved to submit a reply focusing on the Devil instead. In his letter, he endeavors to explain how 'the much-abused Devil may be transformed into an angel of Light' (May 1888, 68). He asserts that the serpent in the Garden of Eden should be seen as corresponding to the brazen serpent lifted up by Moses, a creature with whom May claims Jesus identifies himself. By a somewhat spurious etymology, to put it mildly, he establishes that Satan and God are one and the same, and supports this by stating that 'Serpent worship was universal and symbolical of Wisdom and Eternity'. The basis for the argument is ultimately a metaphysical monism, where there is only one God, though men have given him various names like 'Jupiter, Pluto, Dionysos, God, Devil, Christ, Satan'. (May 1888, 69.)

Headley retorted, refuting May's line of reasoning and ending his letter with the words: 'it is not true, as Mr. May asserts, that good and evil, or Jesus and the Devil, are one and the same' (Headley 1888b, 171). The editor, however, took May's side, and affirmed that, indeed, ' $[t]$ he "Supreme," if IT is infinite and omnipresent, cannot be anything but that. IT must be "good and evil", "light and darkness", etc.' (Editor 1888b, 171). The opportunity was also seized to attack the notion of a personal God and Satan, in spite of Headley having said nothing about subscribing to such a view of the Devil. Headley replied again, this time complaining he felt he had been mis-represented in the debate as believing in the existence of a personal Devil (Headley 1888c). The editorial rejoinder to this was signed H. P. B., instead of simply 'The Editor' (though it seems likely she wrote the earlier ones as well), as if to lend extra weight to the points she makes. The question of Headley being made out to believe in a personal Devil she brushes aside and underscores that the important thing is that such stupid religious superstition is torn down, this endeavor being the very purpose of Lucifer, a magazine which is 'essentially controversial'. (Blavatsky 1888b, 344.) ${ }^{10}$ Blavatsky then expresses her agreement with May's analysis concerning Jesus and Lucifer being the same, and concurs firmly with the monism that underpins it (Blavatsky 1888b, 345). May, just like Blavatsky in The Secret Doctrine, completely dismisses the traditional view of Satan, and reinvents the figure as a perennially misunderstood manifestation of The Supreme. Exactly what this figure is, if not a personal entity, May does not specify.

10 The reason for signing it with her name could also be simply that she became the sole editor of the journal from November 1888 (later, October 1889-June 1891, co-editing it with Besant and at first having shared the duty with Mabel Collins). Kraft 1999, 36. 
The suggestions about Satan made by May cannot have had any influence on Blavatsky's The Secret Doctrine, since the book was published only a month later. ${ }^{11}$ Nothing similar is to be found in Isis Unveiled, and I have not managed to find these ideas in any other Theosophical text published in the interval between Blavatsky's two major books. Therefore, these interpretations must either have been disseminated orally within the society, Blavatsky perhaps directly or indirectly even being the source of May's ideas, or they may have come from an external source. We shall now proceed to look at some possible such sources in the broader contemporary pro-Satan discourse prevalent among socialists and radical artists and authors.

\section{Diabolic Socialism, Art and Romanticism}

Blavatsky's closeness to champions of the proletariat like Charles Sotheran makes it likely she was aware of the use of Satan as a symbol of political liberation in texts by socialists such as Bakunin and Proudhon. In particular, Bakunin's Dieu et l'état (written in 1871, published in 1882), which describes Satan as a gnosis-bringer and makes a positive re-interpretation of the events in the Garden of Eden, could be a potential source of inspiration (Faxneld, forthcoming). Blavatsky's new version of this myth is very similar to the one presented by Bakunin.

As for the name of Blavatsky's journal, we can note that in 1883 an individualist-anarchist weekly newspaper was launched in Kansas (later in Chicago) called Lucifer the Light-bearer. It focused above all on the emancipation of women, and published articles discussing such highly controversial topics as marital rape and contraceptives (Sears 1977). Possibly with inspiration from Proudhon and Bakunin, Lucifer was being used as a name for socialist publications elsewhere as well. Early Swedish social democrats put out coarse propaganda leaflets bearing this title in December 1886 and April 1887, and then in 1891 started a more lavish magazine under the same name (Faxneld, forthcoming). Blavatsky would hardly have been aware of these obscure Swedish publications, but may have known of the American one. What is interesting is that the figure of Lucifer - sometimes, but most often not, completely divorced from the concept of the Devil - was clearly well-established as a symbol of liberation in the radical circles where some of Blavatsky's closest associates moved.

11 The publication date of the book as being mid-October 1888 is given in Santucci 2006, 182-3. 
The premier issue of Blavatsky's journal featured a cover drawing of a comely and noble torch-wielding Lucifer that is extremely similar to that which adorns the Christmas 1893 issue of Lucifer: Ljusbringaren published by the Swedish social democrats. Either the socialists copied the Theosophists' artwork, or they were both using an older image as their model. The latter alternative does not seem improbable, as the figure on both covers closely resembles the heroic Satan in various Romantic works of art, such as Joseph Geefs' L'ange du mal (marble sculpture, 1842), James Barry's Satan and his Legions Hurling Defiance Toward The Vault of Heaven (etching, 1792-94), Henry Fuseli's Satan Summoning his Legions (engraving, 1802) and works by William Blake like Satan in his Original Glory (pen, ink and watercolor, circa 1805) and Satan Arousing the Rebel Angels (watercolor, circa 1805). This iconographic similarity, we should note, embeds the Theosophical journal in an artistic context where Satan is glorified as beautiful, knight-like and majestic.

Of course, Blavatsky, like any other well-read person in the late nineteenth century, was also familiar with the main works of English Romantic Satanists like Byron and Shelley. In her writings, she refers to these authors several times. ${ }^{12}$ In an 1882 article she also discusses the Italian Romantic Giosué Carducci's anticlerical poem 'Inno a Satana' (composed in 1863, published 1865), which is perhaps one of the most programmatic and explicit examples of the tropes of literary Satanism (Blavatsky 1882). It is obvious that Blavatsky's conception of Satan draws on that of the Romantics, at least on a general level. They too, in some of their works, viewed him as a symbol of independence, defiant rebellion and liberation from oppression.

\section{Eve and the Serpent: Blavatsky's Feminist Counter-reading?}

Blavatsky's counter-reading of Genesis 3 may have been inspired, perhaps indirectly, by Bakunin, though this is hard to determine and admittedly remains on the level of mere conjecture. The feminist implications it raises are clearer. Mary Farrell Bednarowski has argued that there are four factors which characterize marginal religious groups which offer leadership roles for women:

(1) a perception of the divine that deemphasizes the masculine, (2) a tempering or denial of the doctrine of the Fall, (3) a denial of the need for a traditional ordained clergy, and (4) a view of marriage which does not hold

12 See the index of Blavatsky's works by Boris de Zirkoff (1991, 94, 503). 
that marriage and motherhood are the only acceptable roles for women (Bednarowski 1980, 207).

In her analysis, she examines how these views are expressed in Shakerism, Spiritualism, Christian Science and Theosophy. ${ }^{13}$ As we have seen, a reinterpretation of the doctrine of the Fall is central to Blavatsky's Satanism. Rather surprisingly, the view of the Fall in Theosophy is not explored at all in Bednarowski's article, though she discusses this point in relation to some of the other groups under scrutiny.

Bednarowski points out that the Garden of Eden narrative has historically served to 'prove' the moral weakness of women, and has been instrumental in excluding women from positions of religious power (Bednarowski 1980, 208). Blavatsky's view of the Fall as a positive, gnosis-bringing event thus implicitly becomes a revaluation of woman: she is no longer responsible for mankind's fall into sin, but is instead actively involved with the gaining of spiritual wisdom from the benevolent snake. Perhaps there were politicalfeminist reasons for Blavatsky to view the Fall thus. As a female religious leader who was bringing esoteric wisdom to mankind, she had every reason to want to smash the old negative view of Eve and the Tree of Wisdom. ${ }^{14}$

In the article 'The Future of Women', published in the October 1890 issue of Lucifer, the feminist Susan E. Gay argues that women and men are but souls temporarily incarnated in female or male bodies, and even in a particular lifetime many women are more male than some men and vice versa. It is therefore inappropriate to impose special restrictions of any kind on women. 'The true ideal in both sexes', she writes, 'is realised in those exceptional but grand characters which possess the best and noblest qualities of both, and who have attained the spiritual equilibrium of duality'. (Gay $1890,118$. $)^{15}$ The blame for the continuing oppression of women is laid at the door of the Church. In this context, Gay brings up the question of the Fall in an interesting way. She relates how a member of the House of Commons in a debate quoted Genesis 3:16 ('Thy desire shall be to thy husband, and he shall rule over thee'), where Eve is cursed by God, and was cheered by other

13 Critiquing Bednarowski, Joy Dixon writes: 'while the features Bednarowski identified were characteristic of theosophy in its first fifty years, many of them were least evident at precisely those moments when women dominated the society' (Dixon 2001, 68).

14 Somewhat contradicting Bednarowski's hypothesis, Blavatsky did believe in a Fall of Man, occuring when mankind started procreating physically, but this was not related to the events in the Garden of Eden, which she saw as positive. On this other Fall in Blavatsky's writings, see Kraft 1999, 85-6.

15 On Gay, see Dixon 2001, 157-9. 
members of the House. Since she is writing for a Theosophical audience well-acquainted with Blavatsky's counter-readings of the Bible in The Secret Doctrine, she then states: 'if the honorable members had been enlightened with regard to the real meaning of those particular chapters dealing with the fall and fate of our race, they might possibly have refrained from such a profound exhibition of ignorance' (Gay 1890,120). What she has in mind is clearly the Blavatskian view of the serpent as a benevolent entity, a bringer of wisdom, and Eve as thus implicitly anything but a cursed creature.

Even if Blavatsky had not explicitly connected this with feminism, some of her adherents obviously did so, and incorporated it into their polemics, which combined esoteric Bible interpretations with political agitation. As Kraft concludes regarding the unconventional lifestyle of women like Blavatsky, even something not intended as a contribution to the feminist struggle may lend it powerful support (Kraft 2003, 126). This, as we can see, applies equally well to the creation of a counter-myth which crushes conventional interpretations of a biblical narrative commonly used to legitimize the oppression of women.

The editors of Lucifer themselves expressly targeted exoteric Christianity as a hindrance for women's emancipation, and in an August 1890 editorial it is stated that demanding franchise reform for females, while at the same time attending churches that oppose freedom for women, is like 'boring holes through sea-water' (Editor 1890, 442). 'It is', the editorial states, addressing Christian suffragettes, 'not the laws of the country that they should take to task, but the Church and chiefly themselves' (Editor 1890, 442). Given such rhetoric, it is hardly far-fetched to suggest that one of the several intentions behind Blavatsky's pro-Satan subversion of Christian myths was to liberate women from the oppression of the original symbolic structures.

\section{The Divine Hermaphrodite, Baphomet and Lady Lucifer}

Blavatsky's esoteric ideas in general also addressed the theme of gender - by denying its ultimate reality, just like her feminist adherent Susan E. Gay did. For Blavatsky, 'esotericism ignores both sexes' and spiritual development, through a series of incarnations, will ultimately lead to the emergence of a spiritual androgyne, a 'Divine Hermaphrodite' (Dixon 2001, 154). ${ }^{16}$ It is tempting to suggest the Theosophical concept of the Divine Hermaphrodite

16 It is worth keeping in mind the distinct cultural traditions behind the terms hermaphroditism and androgynity, and Theosophists occasionally considered them separate phenomena (Kraft 1999, 141). 
was somehow related to Éliphas Lévi's hermaphroditic Devil-figure Baphomet, which was in turn based on older Christian iconography portraying Satan as a being of mixed sex (Faxneld 2010, 12). While she was clearly familiar with Lévi's discussion of this figure, there are only five very brief references to Baphomet in Blavatsky's writings. ${ }^{17}$ Even so, this does not rule out that Lévi's concept of a two-sexed symbol of enlightenment can have influenced her thinking on gender. Explicit connections between the hermaphrodite as a spiritual ideal, Luciferianism, and Baphomet are however not to be found in Blavatsky, in spite of how logical the tying together of these would seem.

Siv Ellen Kraft has made the striking suggestion that Blavatsky herself might have been a physical hermaphrodite. Blavatsky claimed to have been a virgin all her life, in spite of two marriages, and there is even a doctor's certificate to support the assertion that due to injuries sustained from a fall from horseback - resulting in her having, as she put it in a letter, 'all her guts out, womb and all' - she would not have been able to have physical relations with any man. In this letter she further says she is 'lacking something and the place is filled with some crooked cucumber'. Kraft interprets this as a possible reference to hermaphroditism (Kraft 2003, 134). For this condition to have been caused by a riding accident seems a bit strange, however. It could, of course, be an explanation which Blavatsky for some reason provided to account for circumstances present since birth. Whatever her actual genitals were like, it is noteworthy that she rejected traditional womanhood, portrayed herself as an androgyne and signed her personal correspondence Jack. Olcott, who described her as a 'she-male' in his diary, also called her Jack, as did other close friends (Prothero 1993, 215; Kraft 1999, 158). At times, she spoke of an 'indweller', an 'interior man', who could be considered either her higher consciousness or the overshadowing spirit of one of her mysterious Masters (Dixon 2001, 23). Blavatsky's masculinization of herself can be viewed as problematic from a feminist perspective, though it should be noted that feminist appraisals of androgynity and the appropriation of male traits by females have varied widely through history. Given such fluctuations, it seems reasonable to simply conclude, as Kraft does, that Blavatsky did make a feminist contribution by destabilizing gender roles (Kraft 2003, 126).

The fondness for dissolving gender categories also extended beyond Blavatsky herself, to other members' re-imaginings of mythical figures. In

17 Two in The Secret Doctrine (Vol. I, 253; Vol. II, 389), one in Isis Unveiled (Vol. II, 302) and two elsewhere (Zirkoff 1991, 51). 
the October 1887 issue of Lucifer, Theosophist Gerald Massey contributes a poem titled 'The Lady of Light', where he implores: 'Illumine within, as without, us, / Lucifer, Lady of Light!' (Massey 1887, 81). And further: 'With the flame of thy radiance smite / The clouds that are veiling the vision / Of Woman's millennial mission, / Lucifer, Lady of Light!' (Massey 1887, 82). In a footnote, he explains that 'every god and goddess of the ancient pantheons is androgynous' and that 'our Lucifer' is identical with Venus, Istar and Astoreth. Linking this androgynous/female Lucifer to traditionally 'evil' Biblical symbols, he ascertains she is the star Wormwood which St. John observes falling to earth in Revelation 8:10 (Massey 1887, 82). Maintaining an association between Lucifer and 'evil' phenomena whilst feminizing the figure interestingly conjures the image of a Theosophical Satan given womanly features, which might be related to Blavatsky's implicit and explicit revaluation of both.

\section{Conclusion}

The celebrations of Satan are not a key theme in The Secret Doctrine. In total, the passages in question do not constitute a substantial part of the almost 1,500 pages of the two volumes. Checking the index of a fourteen-volume edition of her collected works (which, it is worth noting, does not include The Secret Doctrine and Isis Unveiled) the references to Satanism, the Devil, Lucifer and Satan take up about one and a half pages. This we can then compare to the references to Buddha and Buddhism, which fill over six pages in the index, while the list of references to Christ and Jesus take up a little over four pages. Used in this manner an index is admittedly a rather blunt tool, and we should refrain from overstating the importance of the frequency of occurrence of certain words. It still does say something, and wide reading of Blavatsky's works seems to bear this 'statistical' tendency out. If a figure from religious myth holds a special and prominent position above all others in Blavatsky's writings it is beyond doubt the Buddha (Zirkoff $1991,145-6,311,484,86-92,109-10,260-2)$. Thus, it would be absurd to label Blavatsky a Satanist, if the definition of Satanism used stipulates that Satan must hold the most prominent place in the system in question (cf. Faxneld 2006, xiii-xvi, 108-17). All the same, it remains clear that her probably most influential book contains a fair number of explicit celebrations of Satan, and that this is one of the first instances of such unequivocal praise being heaped on the figure in an esoteric context rather than in the realm of politics or Romantic and Decadent literature. 
Some might object to describing the passages in Blavatsky's works discussed above as 'Satanist', perhaps by arguing that she reinterprets the figure so radically that it is not actually the Christian Satan she is praising. However, this is the case with most Satanists in all periods: the figure they salute is seldom merely a straight reflection of the character from Christian tradition, but is almost always a very differently perceived entity. In this particular case, the figure remains tied to traditional narratives like the Fall, even if these are viewed in an idiosyncratic way. That Blavatsky, in a pioneering manner, applied established tropes of political and literary Satanism in an esoteric context, and was thus instrumental in creating a shift in how the figure came to be viewed by esotericists, can hardly be denied. She exerted a great influence on later esotericists who constructed Satanic systems, such as Ben Kadosh (Carl William Hansen, 1872-1936), Gregor A. Gregorius (Eugen Grosche, 1888-1964) and Pekka Siitoin (1944-2003). In fact, their understanding of Satan could be said to be more or less directly traced on Blavatsky's. To a lesser extent, she may also have inspired how for example Aleister Crowley (1875-1947) and Stanislaw Przybyszewski (1868-1927) perceived the Devil. ${ }^{18}$

Theosophists themselves, on the other hand, seem to have taken little notice of her revaluation of Satan. Perhaps it simply did not fit in well enough with her general 'system', if that is an appropriate word for the often confusing and contradictory worldview Blavatsky presented, and was therefore ignored as irrelevant. Perhaps it was deemed too provoking and therefore rejected as inappropriate to acknowledge. Whatever the explanation, it is more surprising that Theosophy's enemies do not seem have paid much attention to it either. Satanism would of course have been the perfect brush to tar Blavatsky with if one wanted to vilify her, but this tactic was to the best of my knowledge not really employed at the time.

Having established that Blavatsky was no Satanist sensu stricto, what were then her motives for celebrating Satan? This article has suggested several possible reasons. Potentially, feminist goals (at the very least her ideas definitely had feminist implications), or a desire to legitimize her role as a female religious leader, may have played a part. Her 'Satanist' subversion of the myth of the Fall rendered this narrative useless for the time-honored

18 On Kadosh, see Faxneld 2006, 160-175; Faxneld 2011. On Gregorius (whose system is not as explicitly Satanic as those of Kadosh, Siitoin and Przybyszewski), see Faxneld 2006, 177-88. On Siitoin, see Granholm 2009. On Crowley's view of Satan, see Faxneld 2006, 150-60. On Przybyszewski's Satanism, perhaps the first well-developed system of such thought, see Faxneld 2012. 
Christian purpose of 'proving' women's moral weakness. At the time The Secret Doctrine was written, there was a considerable overlap between Theosophy and the women's movement. Rejecting the idea of woman as sinful would hence find a receptive audience among many members. To Blavatsky, the shock value of Satanism could moreover serve a pedagogical function: 'to force the weak-hearted to look truth straight in the face'. Additionally, Satanist counter-readings of the Bible obviously helped undermine the authority of Christianity, the shattering of which was a basic prerequisite for the Theosophical project.

We must also be careful to situate Blavatsky's organization in the political landscape of its time. Theosophy was part of a continuum of progressive agendas, which included feminism, socialism, vegetarianism, anti-imperialism and anti-war efforts (Kraft 1999, 12). Many individuals participating in these efforts were anti-clerical or even anti-Christian. ${ }^{19}$ The pro-Satan provocations of Blavatsky fit well in this context. Similar outbursts were an established part of some types of socialist discourse, and she may have been aware of socialists like Bakunin and Proudhon using Satan as a symbol of liberation.

Another important factor to consider is the influence from evolutionism on Theosophy, even if its exoteric form as proposed by Darwin was repudiated. Breaking free from stasis, by eating the fruit offered by Satan, is logically a desirable event for someone who views the cosmos as evolving ever upwards spiritually. To Blavatsky, who was more or less monist, not only the Fall but also Satan and 'evil' are important for spiritual evolution, which needs (seemingly) antagonistic forces to be dynamic. Several other influences should also be considered. For example, Éliphas Lévi's view of Satan makes the figure a more or less morally neutral force which can also be used for good, and prepares the way for Blavatsky's more radical positive re-imagining (there are also, I should mention, other similarities in their conception of Lucifer, which I have not been able to explore here due to space constraints). The broader non-esoteric cultural environment would have further stimulated this development. For example, pictorial representations of a noble, beautiful Satan were quite common in Romantic art, and Blavatsky was familiar with some of the prime exponents of Romantic literary Satanism: Shelley, Byron and Carducci. All these factors would have given praise of Lucifer a cultural logic, and an instrumental value beyond that of expressing mystical cosmic truths about the figure itself.

19 Naturally, we should also remember that there were quite a few Christian socialists, pacifists, etc. 
Nothing of this is all the same to suggest Blavatsky was not in earnest as an esoteric thinker, nor would I want to take a reductionist approach to her writings and say they were really about something else than esotericism. ${ }^{20}$ However, opting for a religionist stance and viewing esotericism as a lofty, perennial category more or less disconnected from the world at large is not a reasonable alternative either. Rather, I propose that we view her 'Satanism' as an expression of a religious cosmology and as filled with both political implications and strategic didactic maneuvers, all of these strongly colored by contemporary radical use of the figure of Satan. The political implications for the feminist cause of her (limited) 'Satanism' were, as we have seen, picked up on and utilized as a polemical weapon by feminist Theosophist Susan E. Gay when she attacked Christian defenders of patriarchy. Such consequences, as well as the similarities with for example socialist Lucifers, may or may not have been intentional on Helena Petrovna Blavatsky's part. We will never know for sure. Yet, with a shrewd and alert woman like her, it would seem most likely she was fully conscious of quite a few of these dimensions of her 'Satanism' all along.

20 Cf. Kraft 1999, 195-7, and Dixon 2001, 12, where they too argue against dichotomizing religious and 'rational' or political commitments, and Johnson's more pronounced emphasis on the spiritual side of matters (Johnson 1994, 242). 
Bibliography

Sources

Blavatsky, H. P.

1877/1988 Isis Unveiled: A Master-Key to the Mysteries of Ancient and Modern Science and Technology. 2 vols., Pasadena, Calif.: Theosophical University Press.

1882 Masons and Jesuits. - The Theosophist, Vol. III, No. 7, 174-5.

1888a The Secret Doctrine. Pasadena, Calif.: Theosophical University Press. 1888b The Editor's Reply. - Lucifer, Vol. III, No. 16, 344-5.

1890 The Mote and the Beam. - Lucifer, Vol. VI, No. 36, 470-8.

\section{'Editor'}

1887 What's in a Name? Why the Magazine is Called Lucifer. - Lucifer Vol. I, No. 1, 1-7.

1888a Editor's Note. - Lucifer, Vol. II, No. 12, 497.

1888b Editor's Notes. - Lucifer, Vol. III, No. 14, 171-2.

1890 Progress and Culture. - Lucifer, Vol. VI, No. 36, 441-50.

Gay, Susan E.

1890 The Future of Women. - Lucifer, Vol. VII, No. 38, 116-22.

Headley, T. G.

1888a The Devil! Who is He? Jesus, or the Priest? - Lucifer, Vol. II, No. 12, 495-7.

1888b The Devil-Who is He? - Lucifer, Vol. III, No. 14, 170-1.

1888c The Devil, Who is He? - Lucifer, Vol. III, No. 16, 343.

Lévi, Éliphas

1860 Histoire de la magie. Paris: Germer Bailiérre.

Massey, Gerald

1887 The Lady of Light. - Lucifer, Vol. I, No. 2, 81-2.

May, Thomas

1888 The Devil, Who is He? - Lucifer, Vol. III, No. 13, 68-71.

\section{Literature}

\section{Bednarowski, Mary Farrell}

1980 Outside the Mainstream: Women's Religion and Women Religious Leaders in Nineteenth-Century America. - Journal of the American Academy of Religion, (48), 2, 207-31. 


\section{Campbell, Bruce F.}

1980 Ancient Wisdom Revived. A History of the Theosophical Movement. Berkeley, Los Angeles, London: University of California Press.

\section{Dixon, Joy}

2001 Divine Feminine. Theosophy and Feminism in England. Baltimore \& London: The Johns Hopkins University Press.

\section{Eliade, Mircea}

1976 Occultism, Witchcraft and Cultural Fashions. Chicago, London: University of Chicago Press.

\section{Faxneld, Per}

2006 Mörkrets apostlar. Satanism i äldre tid. Sundbyberg: Ouroboros.

2010 Djävulen är en kvinna. Inledning. - Jacques Cazotte, Den förälskade djävulen. Ockult roman från 1772, 1-29. Stockholm: Malört förlag.

2011 The Strange Case of Ben Kadosh. A Luciferian Pamphlet from 1906 and its Current Renaissance. - Aries. Journal for the Study of Western Esotericism, 11 (1), 1-22.

2012 Witches, Anarchism, and Evolutionism: Stanislaw Przybyszewski's fin-de-siècle Satanism and the Demonic Feminine. - Per Faxneld \& Jesper Aa. Petersen (eds), The Devil's Party. Satanism in Modernity, 53-71. Oxford \& New York: Oxford University Press.

Forthcoming The Devil is Red.Socialist Satanism in Nineteenth and Early Twentieth Century Europe, accepted for publication in Numen. International Review for the History of Religions.

\section{Godwin, Joscelyn}

1994 The Theosophical Enlightenment. Albany: State University of New York Press.

\section{Granholm, Kennet}

2009 'Worshipping the Devil in the Name of God'. Anti-Semitism, Theosophy and Christianity in the Occult Doctrines of Pekka Siitoin. - Journal for the Academic Study of Magic, 5, 256-86.

\section{Hammer, Olav}

1999 Profeter mot strömmen. Essäer om mystiker, medier och magiker i vår tid. Stockholm: Wahlström \& Widstrand.

\section{Hutton, Ronald}

1999 The Triumph of the Moon. A History of Modern Pagan Witchcraft. Oxford \& New York: Oxford University Press.

\section{Johnson, K. Paul}

1994 The Masters Revealed. Madame Blavatsky and the Myth of the Great White Lodge. Albany: State University of New York Press. 
1995 Initiates of Theosophical Masters. Albany: State University of New York Press.

\section{Kraft, Siv Ellen}

1999 The Sex Problem. Political Aspects of Gender Discourse in the Theosophical Society, 1875-1930 (diss.). Department of the History of Religions, Bergen: University of Bergen.

2003 'There is Nothing of the Woman in Me'. Madame Blavatsky, Teosofi og Utopisk Feminisme. - Tone Hellsund, \& Inger Marie Okkenhaug (eds), Erobring og Overskridelse. De Nye Kvinnene Inntar Verden 1870-1940, 125-42. Oslo: Unipub Forlag.

\section{Lejon, Håkan}

1997 Historien om den antroposofiska humanismen. Den antroposofiska bildningsidén i idéhistoriskt perspektiv 1880-1980. Stockholm: Almqvist \& Wiksell.

\section{Prothero, Stephen}

1993 From Spiritualism to Theosophy. 'Uplifting' a Democratic Tradition. - Religion and American Culture (3) 2, 197-216.

\section{Santucci, James A.}

2006 Blavatsky, Helena Petrovna. - Wouter J. Hanegraaff (ed.), Dictionary of Gnosis E Western Esotericism, 177-85. Leiden \& Boston: Brill.

\section{Sears, Hal D.}

1977 The Sex Radicals. Free Love in Victorian America. Lawrence: The Regent Press of Kansas.

\section{Sellon, Emily B. \& Renée Weber}

1992 Theosophy and the Theosophical Society. - Antoine Faivre, \& Jacob Needleman (eds), Modern Esoteric Spirituality, 311-29. New York: Crossroad.

\section{Szalczer, Eszter}

1997 Strindberg's Cosmic Theatre. Theosophical Impact and the Theatrical Metaphor (PhD diss., City University of New York). Ann Arbor, MI: UMI Dissertation Publishing ProQuest.

\section{Zirkoff, Boris de (compiler)}

1991 H. P. Blavatsky. Cumulative Index. Wheaton, Ill., Madras \& London: The Theosophical Publishing House. 